J. E. McAllister, J. L. Mott Co., Trenton, N. J.

Frank E. Lauer, 2389 Mance St., Montreal, Canada.

J. P. Callaghan, Sharon Clay Products Co., Sharon, Pa.

C. B. Young, Ohio State Brick \& Stone Co., Newark, Ohio.

Maurice A. Smith, McKee Glass Co., Jeanette, $\mathrm{Pa}$.

Harry A. Truby, Pittsburgh Plate Glass Co., Creighton, Pa.

H. Homer Knowles, Box 427, East Liverpool, Ohio.

Fenwick D. Foley, St. John, N. B.

Paul R. Morris, 300 East gth Ave., Tarentum, Pa.

N. B. Radabaugh, 1572 Rydal Mt. Rd., Cleveland, Ohio.

\title{
LOCAL SECTION MEETINGS.
}

\section{NEW ENGLAND SECTION.}

Boston, Mass., January 11, 1919.

The meeting was called to order by Chairman A. A. Klein at the Boston City Club, at 7 P.M., with twenty members present.

Mr. Klein spoke of the recent death of Mr. C. L. Walduck and his loss to the Society. It was voted that a committee be appointed by the chair to draw up resolutions and that copies be sent to his parents and to the American Ceramic Society.

Later in the evening the committee reported as follows:

"We, members and appointed representatives of the New England Section of the American Ceramic Society, in remembrance of the sterling qualities of Charles L. Walduck personally and his efficient services as Secretary of this Section, wish to record our much felt loss of him as a man and as Secretary of this Section. We extend our sympathies to his parents and recommend to our parent organization, the American Ceramic Society, a suitable obituary notice in their Journal."
W. G. Whitmore,
R. C. Purdy,
M. F. Cunningham.

The officers elected for the coming year were:

Chairman, W. H. Grueby, Grueby Faience \& Tile Co., Boston, Mass.; Secretary and Treasurer, Charles J. Hudson, Norton Co., Worcester, Mass.; Councilor, Charles H. Kerr, American Optical Co., Southbridge, Mass. 
Mr. R. C. Purdy spoke interestingly on the purpose of the Section both as regards itself and its relation to the American Ceramic Society. Two interesting and valuable talks followed:

"Some Problems of the Glass Manufacturer," by C. H. Kerr of the American Optical Company and "Clay Testing Methods and Purposes," by Carl H. Lawson of the Norton Company, Worcester, Mass. A general discussion of the papers followed.

During the afternoon previous to the meeting the members enjoyed a trip through the chemical laboratories of Arthur D. Little, Inc.

Charles J. Hudson, Secretary.

\section{PITTSBURGH DISTRICT SECTION.}

At a meeting held at the Mellon Institute, University of Pittsburgh, Pittsburgh, Pa., December 19, 1918, the merging of the former Beaver Section into the Pittsburgh District Section was completed. Morning and afternoon sessions were held.

At the opening of the morning session by-laws were adopted and the following officers were elected for the ensuing year: R. R. Hice, Chairman, C. R. Peregrine, Vice-Chairman, Thos. H. Sant, Treasurer, F. H. Riddle, Secretary and F. W. Walker, Sr., Councilor.

After the election of officers a varied and interesting program of technical papers was afforded as follows:

"Industrial Research," Dr. E. W. Tillotson, Mellon Institute.

"The Effect of Some Fluxes on Porcelain," F. H. Riddle, Bureau of Standards.

"The Influence of Some Ball Clays upon the Casting of Clay Wares," J. W. Wright, Bureau of Standards.

"The Hydraulic Properties of the Calcium Aluminates," P. H. Bates, Bureau of Standards.

"Note on the Electrical Resistance of Porcelains at Temperatures up to $800^{\circ} \mathrm{C}$," A. V. Bleininger, Bureau of Standards.

Members desiring to become affiliated with the above Section should communicate with the Secretary, F. H. Riddle, Bureau of Standards, 4oth and Butler Sts., Pittsburgh, Pa. 